\title{
Attacks and damage of termites (Insecta: Isoptera) in different cocoa agroforestry systems (Nawa, Côte d'Ivoire).
}

\author{
SIB Ollo ${ }^{1}$, SORO Senan ${ }^{2}$, TRA BI Crolaud Sylvain ${ }^{2}$. \\ 1 Université Jean Lorougnon Guédé de Daloa, UFR Environnement, Laboratoire de Biodiversité et Gestion Durable des \\ Ecosystèmes Tropicaux, BP 150 Daloa. \\ ${ }^{2}$ Université Jean Lorougnon Guédé de Daloa, UFR Agroforesterie, Laboratoire d'Amélioration des productions agricoles / \\ Entomologie Agricole.
}

Corresponding author: sibollo28@yahoo.com

Key words: Cocoa trees, Termites, damage, agroforestry system.

Publication date 30/04/2020, http://m.elewa.org/Journals/about-japs/

\section{$1 \quad$ ABSTRACT}

To maintain its status of leading producer of cocoa in the world, Côte d'Ivoire must be contain the different types of threats, including the emergence of termites in cocoa farms. This study was conducted in the south-west of the country to evaluate the effect of cropping systems (full sun system, intermediate system and shaded system) on termite attacks. The study was conducted in four localities with different cocoa agroforestry systems. The sampling was made on cocoa trees in quadrats of $30 \mathrm{mx} 30 \mathrm{~m}$ and the attack rate was calculated. Eleven (11) termite species were identified. The wood-feeders groups were dominant. These termites were responsible for $41.82 \%$ of the damage on cocoa trees. Termite Attacks vary between different cropping systems. Full sun systems were most attacked comparing to intermediate shade systems that were least attacked by termites. This work shows that the shade system has an effect on termite attacks in cacao trees. The choice of right system can help to significantly reduce termite attacks in cocoa farms.

\section{INTRODUCTION}

Cocoa is a commercial crop of great importance around the world. With a worldwide production of more than 4 million tons of beans in 2019, cocoa has become a vital export product for many countries, especially in West Africa (Vos et al., 2003, ICCO, 2019). Two-thirds of world cocoa production is grown in Africa and the majority is produced by Côte d'Ivoire and Ghana. Côte d'Ivoire supplies about $40 \%$ of the world supply of cocoa beans and has been leader producer among the 50 or so produce countries for more than 30 years (Anonymous, 2007). Cocoa cultivation occupies a key place in the economy and is a main source of income for thousands of small farmers in rural areas. Cocoa cultivation accounts $40 \%$ of export earnings and contributes more than 15\% to Gross Domestic Product (Dufumier, 2016). In the Nawa' region of the country' south-west, which is now considered as the new Ivorian cocoa loop, much agricultural exploitation supports thousands of people. This crop is now subject to high parasite pressure due to diseases and pests (Tra Bi, 2013). The most common cacao pests in Côte d'Ivoire are mirids, stem borers and brown pod rot. To this, the swollen shoot advent and the termites emergence wreak havoc in cocoa farms. In Côte d'Ivoire, there is little data on termite attacks on cocoa trees.

Termite's impact is important in tropical soils evolution (Bignell and Eggleton, 2000). They influence pedogenesis, physicochemical 
properties and soil functions (Su, 2002). Termites are also considered important decomposers in the semi-arid tropic areas where they are an important role in nutrient cycle (Holt, 1996). In spite of their important roles in ecosystems, termites are also known for the damage they cause. According to Wood (1976), termites are one of the largest groups of pests. About $10 \%$ of termite species have negative impacts on homes and crops (Constantino, 2002). Termite crop losses are enormous and are in the range of $20-45 \%$ (Wood and Pearce 1991). In Côte d'Ivoire, Akpesse et al. (2001) showed termite damage on

\section{MATERIAL AND METHODS}

3.1 Study area: This study was conducted in four localities in the Nawa region of southwestern Côte d'Ivoire (Figure 1). Sixteen (16) cocoa plots were selected in the four localities at the rate of four (4) plots per locality. The Plots differ from one locality to another depending on shade intensity. In the localities of Takoragui $\left(05^{\circ} 45^{\prime} 18^{\prime \prime} \mathrm{N}, 06^{\circ} 47^{\prime} 30^{\prime \prime} \mathrm{W}\right)$ and Gnaboya $\left(06^{\circ} 04^{\prime} 31^{\prime \prime} \mathrm{N}, 6^{\circ} 54^{\prime} 35^{\prime \prime} \mathrm{W}\right)$, respectively the full sun system and the shaded system were selected. The localities of Petit Bouaké (05 56 47" N, 06 19' 46" W) and Bobouho $1\left(05^{\circ} 35^{\prime} 33^{\prime \prime} \mathrm{N}, 06^{\circ} 01^{\prime} 53^{\prime \prime} \mathrm{W}\right)$ are characterized by and intermediate system. Between the two cropping systems, the first is close to full sun system (Petit Bouaké) while the rice and maize crops. In cocoa farms, Tra bi et al. (2013) showed that termites are veritable attackers of cocoa trees in Oumé area. Termite attacks in cocoa farms are growing year by year due to massive deforestation and climate change. Given that overriding interest of cocoa farming, it is important to identify termite's pest's species in cocoa agroforestry systems and to assess the importance of termite damage in different agroforestry systems in order to develop cocoa agroforestry system allow to limit the risk of termite attacks and the development of adequate control methods.

second is close to shaded system (Bobouho 1). Nawa region is one of the largest areas of cocoa production in Côte d'Ivoire. It accounts for about $20 \%$ of national production of cocoa beans. This region is located in Guinean forest area and has a typical equatorial climate. The region is characterized by two rainy seasons and two dry seasons. The rainy seasons are from April to June and September to October, while the dry seasons are from November to March and July to August. The annual rainfall varies between $1600 \mathrm{~mm}$ and $2000 \mathrm{~mm}$. the average temperature varied from $24^{\circ} \mathrm{C}$ and $27^{\circ} \mathrm{C}$. The soils of the region are ferralitic types (Ageroute, 2013). 


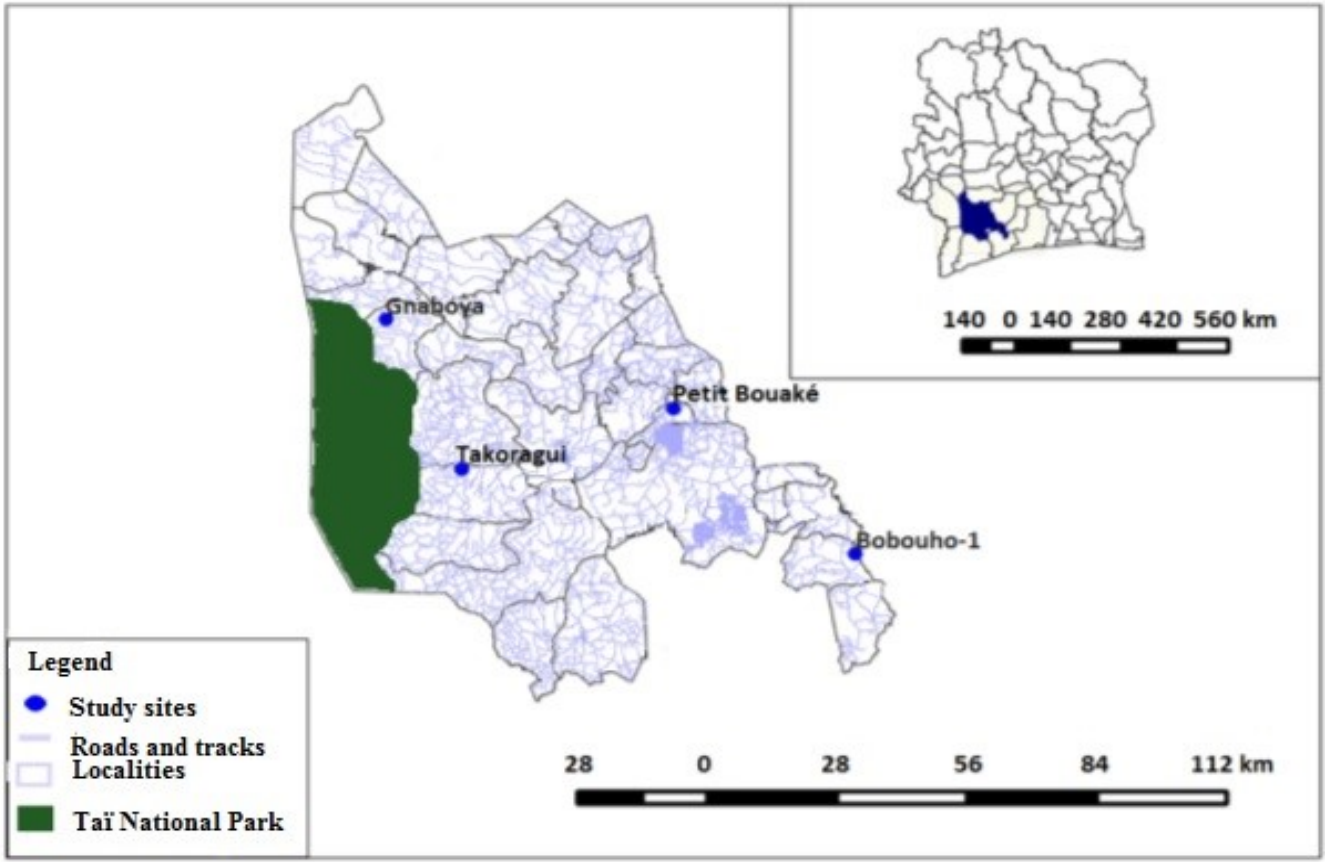

Figure 1: Localisation of the study area

3.2 Data sampling: Termites were collected on cocoa trees (young, mature and aged cocoa trees) in quadrats of $30 \mathrm{~m} \times 30 \mathrm{~m}$. In each cocoa plot, four (4) quadrats of $30 \mathrm{~m} \times 30 \mathrm{~m}$ were installed and in each locality, four (4) plots were selected. In total, sampling was carried out in sixty-four (64) quadrats. For each sampling unit, termites were collected from roots, stems, fissures, nests, galleries and cocoa veneers. The presence of trace, veneer, gallery or termite nest on a cocoa tree was considered as an attack. All cocoa trees in the sampling area were examined to determine the proportion of these cocoa trees with termite damage.

\subsection{Termite identification: Termites} harvested were identified in the laboratory of biology and tropical ecology of the University Jean Lorougnon Guédé of Daloa. Specimens were determined up to the level of species using various documents such as Hamad (1950), Bouillon and Mathot (1965), Sands (1965, 1972, 1998). After identification, each species was classified into one of the trophic groups.

3.4 Data analysis: Termite attack rate is estimated based on the principle of Han and Ndiaye (1996). Organ is said to be attacked when it carries galleries or veneers with or without termites. Termite attacks on cocoa trees have been classified into 2 groups. The classification was based on the density of the veneers and especially on the progression of termites in the anatomical structures of the plant. Thus, cocoa trees were classified into three categories: (0) absence of termites, (1) presence of tracks, nest and superficial damage (type I damage), and (2) internal damage, i.e. damage below the bark (type II damage).

Termite attack rate by locality were calculated according to the following formula:

$\mathrm{Ta}=\mathrm{Npa} \times 100 /$ Ntp

$\mathrm{Ta}=$ Termite attack rate by locality

$\mathrm{Npa}=$ Number of cocoa feet with termite attacks

Ntp $=$ Total number of cocoa feet observed by locality.

The frequencies obtained made it possible to group species into different classes based on the coding of the frequencies index (Ouedraogo et al., 2015).

Data were subjected to variance (ANOVA) analysis and were compared with the KruskalWallis test at 5\% threshold with statistica software version 7.1. 


\section{$4 \quad$ RESULTS}

4.1 Termite's diversity: A total of 11 termite species grouped divided into 7 genera, 4 subfamilies and 3 families were collected into cocoa plants (Table 1). Wood-feeders with 7 species are the most diversified. Three species of fungus-growers were harvested. Grassfeeders are least represented with one species. Two species are common to all localities: Microcerotermes fuscotibialus and Nasutitermes arborum. Gnaboya' locality with 6 species, records the largest number of termite species.
Wood-feeders termites were the most common group in the four localities with rates ranging from 80 to $100 \%$ of the sampled population (table 4). Fungus-growers rate was greater in the shaded system (Gnaboya) with $20 \%$ of populations sampled compared to $3.03 \%$ in full sun system (Takoragui). This group does not exist in intermediate shade systems. The last group (grass-feeders) was observed only in the intermediate shade system (Petit Bouaké) with $4.54 \%$ of the samples collected.

Table 1: List of termite species collected in cocoa trees of the different habitats

\begin{tabular}{|c|c|c|c|c|c|c|c|}
\hline Family & Sub-family & Species & Takoragui & Petit Bouaké & Bobouho 1 & Gnaboya & TG \\
\hline Rhinotermitidae & Rhinotermitinae & \multicolumn{2}{|c|}{ Schedorbinotermes lamanianus } & & $*$ & & $\mathrm{X}$ \\
\hline \multirow[t]{9}{*}{ Termitidae } & \multirow[t]{5}{*}{ Macrotermitinae } & Ancistrotermes cavithorax & & & & $*$ & $\mathrm{C}$ \\
\hline & & Ancistrotermes guineensis & * & & & $*$ & $\mathrm{C}$ \\
\hline & & $\begin{array}{l}\text { Microcerotermes } \\
\text { fuscotibialus }\end{array}$ & $*$ & $*$ & $*$ & $*$ & $\mathrm{X}$ \\
\hline & & Microcerotermes parvus & & $*$ & & & $\mathrm{X}$ \\
\hline & & Microtermes thoracalis & & & & $*$ & $\mathrm{C}$ \\
\hline & \multirow[t]{4}{*}{ Nasutitermitinae } & Nasutitermes arborum & $*$ & $*$ & $*$ & $*$ & $\mathrm{X}$ \\
\hline & & Nasutitermes diabolus & $*$ & & & $*$ & $\mathrm{X}$ \\
\hline & & Nasutitermes latifrons & $*$ & $*$ & $*$ & & $\mathrm{X}$ \\
\hline & & Trinervitermes geminatus & & $*$ & & & $\mathrm{~F}$ \\
\hline Kalotermitidae & Kalotermitinae & $\begin{array}{l}\text { Postelectrotermes } \\
\text { sordwane }\end{array}$ & & & * & & $\mathrm{x}$ \\
\hline Total & & 11 & 5 & 5 & 5 & 6 & \\
\hline
\end{tabular}

C: fungus-growers; H: Soil-feeders; X: Wood-feeders; F: grass-feeders; TG: Trophic group

Table 2: Rate of the different trophic groups in the different localities ( $\%)$

\begin{tabular}{lcccc}
\hline Locality & Takoragui & Petit Bouaké & Bobouho 1 & Gnaboya \\
\hline Fungus-growers & 3.03 & - & - & 20 \\
Wood-feeders & 96.97 & 95.45 & 100 & 80 \\
Grass-feeders & - & 4.54 & - & - \\
\hline
\end{tabular}

4.2 Assessment of termite attacks on cocoa trees in different agroforestry systems: Eleven (11) species of termite collected are responsible for $41.82 \%$ damage on cocoa trees. Traces of termite activities have observed in a large number of cocoa trees in the different shade systems. Termite attacks mainly concern the roots, the stems and the branches of cocoa trees. Data analysis showed a significant difference between termite attacks in different shade systems ( $\mathrm{p}=0.001$, KruskalWallis test). Termite attacks are higher in the full sun system, while the intermediate systems have least attacked. In intermediate management systems, the average attack rate is $29.1 \%$ and $27.87 \%$ respectively for the localities of Petit Bouaké and Bobouho 1. However, in the full sun system, the average infestation rate was $61.49 \%$. In shaded systems, the infestation rate was $44.32 \%$. Two categories of damage were observed on cocoa trees (figure 2). Minor damage (T1) with $87.97 \%$ of rate on the damage observed is the largest, while Major Damage (T2) accounted for $12.03 \%$ of damage 
to cocoa trees. The categories (two) of damage are higher in full sun systems ( $\mathrm{T} 1=54.23 \%$; $\mathrm{T} 2=7.26 \%$ ) (Figure 3). The lowest rates of the two categories of damage were observed in the intermediate systems. In all cocoa trees observed, $36.79 \%$ of cocoa trees bear Type I of termite attacks while the major damage accounts for $5.03 \%$ of the cocoa trees. There was a rate of $58.18 \%$ of healthy cocoa trees. From the analysis of quantitative results, it appears that type I damage is numerically higher compared to type II damage in all localities. However, these types of attacks differ and vary according to age of the plantations and shade system type. Attack rate of the 11 species were compared across shade systems to identify the most aggressive species on cocoa trees. In all management systems, the average attack rate of the termite species is statistically identical (ANOVA, $\mathrm{p}=0.057$ ). However, the comparison of termite attacks by locality and species reveals that the species Nasutitermes
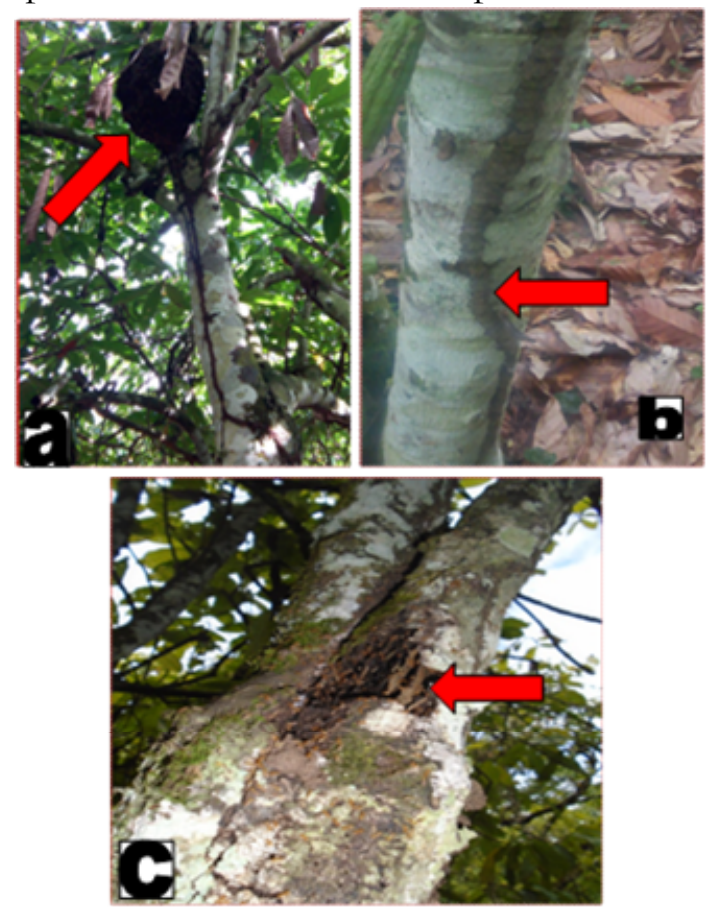

Fig. 2: Termite damage on cocoa trees

(b: minor damage; a \& c: major damage) latifrons and Nasutitermes diabolus are the most aggressive species in the full sun system (figure 4). In the intermediate shade systems Nasutitermes latifrons, Nasutitermes arborum and Microcerotermes fuscotibialus species caused the most damage. The species Nasutitermes diabolus, Nasutitermes arborum and Microcerotermes fuscotibialus are the termites caused the most damage in the shaded system (table 3), termite species can be divided into four classes at Petit Bouaké; three classes in Takoragui and Gnaboya; two classes at Bobouho 1 (Table 4). Thus, at Takoragui two accessory species, one accidental species and two very rare species were sampling. The first intermediate system (Petit Bouaké) contends one quite common species, one accessory species, one accidental species and two very rare species. Three accessory species and two very rare species characterize the second intermediate system (Bobouho 1) and the shaded system in which we also find an accidental species.

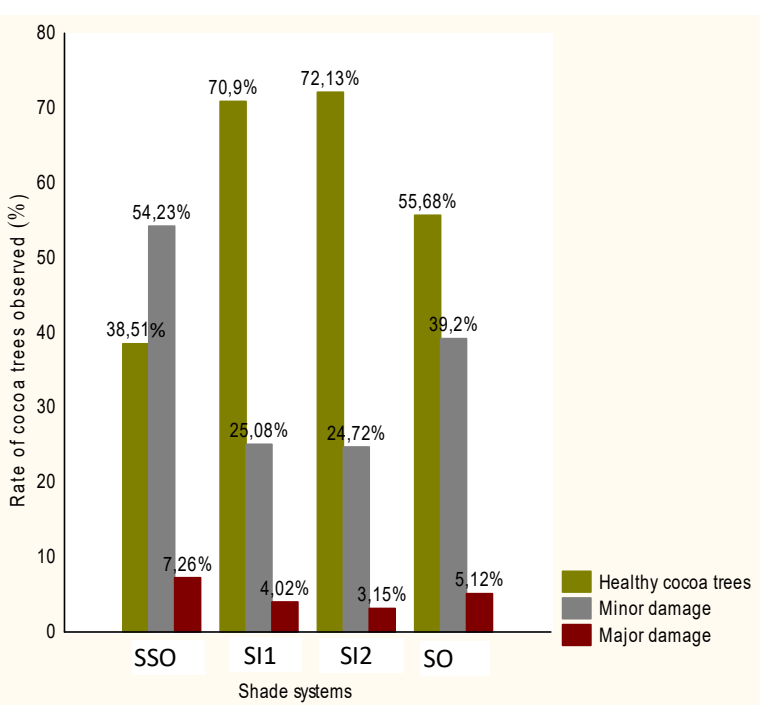

SSO : Full sun system ; SI : Intermediate system ; SO : Shaded system

Fig.3: Type of damage observed on the cocoa trees 


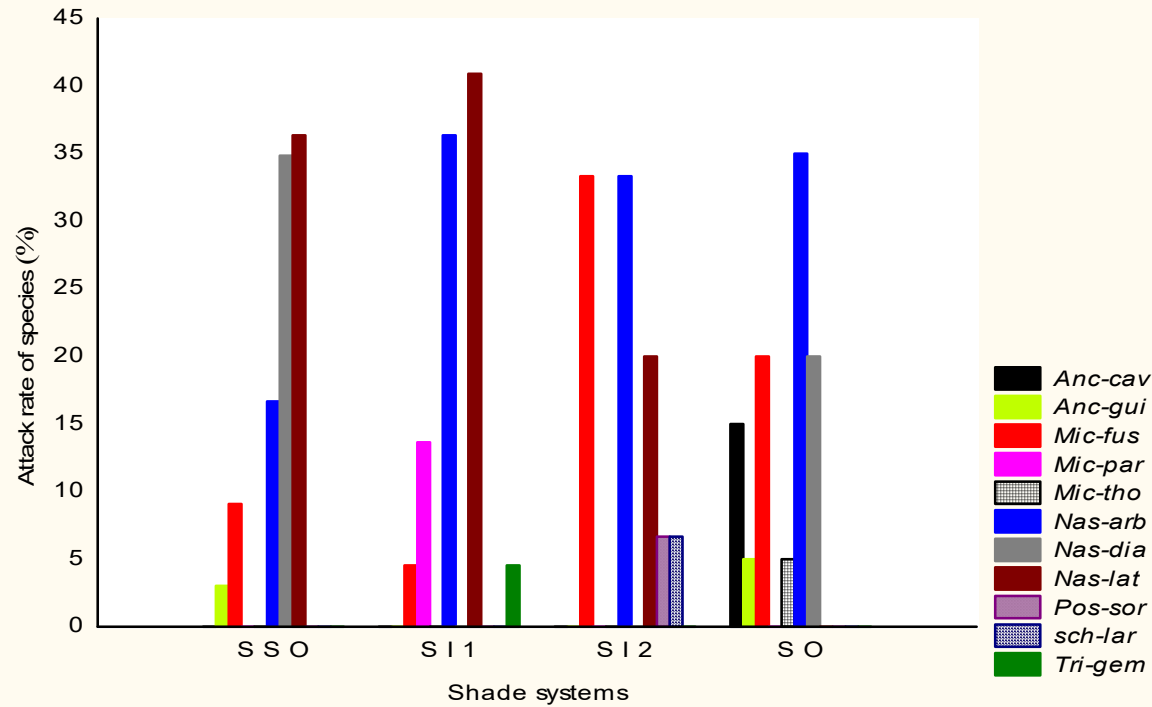

Anc-cav : Ancistrotermes cavithora; Anc-gui :Ancistrotermes guineensis; Mic-fus : Microcerotermes fuscotibialus; Mic-par : Microcerotermes parvus; Mic-tho : Microtermes thoracalis; Nas-arb: Nasutitermes arborum; Nas-dia: Nasutitermes diabolus; Nas-lat: Nasutitermes latifrons; Pos-sor: Postelectrotermes sordwane; Scb-lar: Schedorbinotermes lamanianus ; Tri-gem : Trinervitermes geminatus. ; SSO: Full sun system; SI: Intermediate system; SO: Shaded system.

Fig. 4: Attack rate according to termite's specie

Table 3: Codification of rate indexes (Ouedraogo et al., 2015)

Frequency classes (\%)

$\mathrm{F}<10$
$10<\mathrm{F}<20$
$20<\mathrm{F}<40$
$40<\mathrm{F}<60$
$60<\mathrm{F}<80$
$\mathrm{~F}>80$

Very rare species

Accidental species

Accessory species

Quite frequent species

Frequent species

Very frequent species 
Table 4: Classification of species according to frequencies

\begin{tabular}{|c|c|c|c|c|c|}
\hline $\begin{array}{l}\text { Frequencies } \\
(\%)\end{array}$ & Characteristics & $\begin{array}{l}\text { Full sun system } \\
\text { (Takoragui) }\end{array}$ & $\begin{array}{l}\text { Intermediate system(Petit } \\
\text { Bouake) }\end{array}$ & $\begin{array}{l}\text { Intermediate system (Bobouho } \\
\text { 1) }\end{array}$ & $\begin{array}{l}\text { Shaded system } \\
\text { (Gnaboya) }\end{array}$ \\
\hline $40<\mathrm{F}<60$ & Quite frequent spec & & Nasutitermes latifrons (40.91\%) & & \\
\hline $20<\mathrm{F}<40$ & Accessory species & 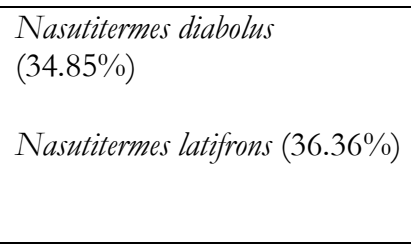 & Nasutitermes arborum (36.36\%) & $\begin{array}{l}\text { Microcerotermes fuscotibialus (33.33\%) } \\
\text { Nasutitermes arborum }(33.33 \%) \\
\text { Nasutitermes latifrons }(20 \%)\end{array}$ & $\begin{array}{l}\text { Microcerotermes } \\
\text { fuscotibialus (20) } \\
\text { Nasutitermes arborum } \\
(35 \%) \\
\text { Nasutitermes diabolus } \\
(20 \%)\end{array}$ \\
\hline $10<\mathrm{F}<20$ & Accidental species & $\begin{array}{l}\text { Nasutitermes arborum } \\
(16.67 \%)\end{array}$ & Microcerotermes parvus (13.65\%) & & $\begin{array}{l}\text { Ancistrotermes cavithorax } \\
(15 \%)\end{array}$ \\
\hline $\mathrm{F}<10$ & Very rare species & $\begin{array}{l}\text { Ancistrotermes guineensis (3.03) } \\
\text { Microcerotermes fuscotibialus } \\
(9.09)\end{array}$ & $\begin{array}{l}\text { Microcerotermes fuscotibialus } \\
(4.54 \%) \\
\text { Trinervitermes geminatus }(4.54 \%)\end{array}$ & $\begin{array}{l}\text { Postelectrotermes sordwane }(6.67 \%) \\
\text { Schedorhinotermes lamanianus }(6.67 \%)\end{array}$ & $\begin{array}{l}\text { Ancistrotermes guineensis } \\
(5 \%) \\
\text { Microtermes thoracalis } \\
(5 \%)\end{array}$ \\
\hline
\end{tabular}




\section{DISCUSSION}

Eleven (11) species of termites on cocoa trees in the four cocoa agroforestry systems were sampled. These results are similar to those obtained by Ano et al. (2018) and very close to the result of Tra Bi (2013) who obtained respectively 11 species and 12 species in the cocoa plantations of Abengourou for the first and Oumé for the second. Most of these species belonging to the wood-feeders and fungus-growers. These two groups of termites are responsible for the damage observed on mango trees in northern Côte d'Ivoire (Coulibaly et al., 2014). No soil-feeders species were harvested from cocoa trees. The species of Microcerotermes fuscotibialus and Nasutitermes arborum are common to all localities. These species build galleries that show perforations in the bark of infested cocoa trees that often cause their death. The work in tropical Africa has shown that Macrotermitinae (Mora et al., 1990, Wood and Pearce, 1991) and Nasutitermitinae (Pretorius et al., 1991, Mampouya, 1997) are responsible for important plantation damage. According to the results, most of the infestations are type I $(87.97 \%$ of the cocoa trees attacked). These results are in agreement with those obtained by Coulibaly et al. (2018) who observed higher rates of Type I termite damage on trees at the Korhogo University campus in northern Côte d'Ivoire. This high rate is due to the attack mode of different species of termites. Indeed, most termites build veneers on the trunks of plants. These veneers serve as protection to attack the plant (Gbenyedji et al., 2016). The evaluation of termite attack rates showed that attacks were more common in full sun systems (61.49\%),

\section{CONCLUSION}

This study highlights the effect of cultivation systems on termite attacks and show that termites are important pests for cocoa farming. Eleven species of termite's pests were collected from cocoa trees in different shade systems. These termites were responsible for $41.82 \%$ of while in intermediate management systems were the least attacked. The attack rate of termites is variable according to plots and shade systems. Cocoa farmers who estimated that termite infestations increased with the growing elimination of shade trees (Djuideu et al. 2019) observed this state of fact. The high rate of termite attacks in full sun systems could be explained by the vulnerability of the full sun system from attack of insect pests. The plots of full sun systems in the study area are older plantations and this could have an effect on installation and termite attacks. Tra bi (2013) showed that the age of plots influence termite attacks. Anani Kotoklo et al. (2010b) observed that the incidence and intensity of termite attacks vary according to the species, the locality and the edaphic factors. Termite attacks can be related on nature of soil (ferralitic red soil) that would favour the installation of termite mounds, sources of plant infestations (Gbenyedji et al., 2016). The study showed that intermediate systems are the least attacked by termites, especially those close to shaded systems. Indeed, the plots of this system recorded less termite attack than the plots of other management systems. This low attack rate of termites in this intermediate system very close to the shaded system could be explained by composition and complexity of this system. Several factors, including the shade and diversity of shade trees, would also influence termite's installation in these plots. Face to the proliferation of termites in cocoa plantations, intermediate management systems could reduce the emergence of termites and limit the risk of attack.

attacks on cocoa trees. These species were classified into three trophic groups in which, Wood-feeders were the most important. The results obtained show that the type of agro system cultivation influences the termite attack. 


\section{$7 \quad$ ACKNOWLEDGEMENTS}

The authors renew their thanks to producers and technicians of the villages of the localities studied, in particular the farmers who were kind enough to make their plantations available.

\section{REFERENCES}

Ageroute : 2013.Travaux pour l'amélioration de l'état du réseau prioritaire de pistes, agricoles dans la région de la Nawa (Soubré et Guéyo). Rapport révisé 1, $362 \mathrm{p}$.

Akpesse AA, Kouassi P, Yapi A, Lepage M, Tano Y. and Tahiri A : 2001. Influence des traitements insecticides sur les populations de termites nuisibles aux cultures de riz et de maïs en milieu de savane (Lamto et Booro-Borotou, Côte d'Ivoire). Agron. Afr, 13: 45-94.

Anani Kotoklo E, Kasseney BD, Nyamador W, Ketoh GK. and Glitho AI: 2010. Attaques des arbres par les termites sur le campus de l'Université de Lomé (Togo). Int. J. Biol. Chem. Sci., 4(1): 6169.

Ano EJ, Tahiri A, Siapo YM. and Diby YKS: 2018. Comparative study of diversity and termite damage in the selected variety of cocoa "Mercedes or CNRA" and unselected "Tout venant" grown in Abengourou in eastern Côte d'Ivoire. International Journal of Entomology Research, 3(4: 27-35).

Bignell D. and Eggleton P: 2000. Termites in ecosystems. In: Termites: Evolution, Sociality, Symbioses, Ecology. (Abe T, Bignell D.E. \& Higashi M. (eds). Kluwer Academic Publisher, Amsterdam, p. 363-387.

Bouillon A. and Mathot G: 1965. Quel est ce termite africain ? Zoo. Suppl., 1: 1-23.

Constantino R: 2002. The pest termites of South America: Taxonomy, distribution and statuts. Journal. Applied. Entomology, 126: 355-365.

Coulibaly T, Akpesse A, Yapi A, Zirihi G. and Kouassi KP: 2014. Dégâts des termites dans les pépinières de manguiers du
These thanks are also addressed to the different officials and village chiefs of the different localities.

nord de la Côte d'Ivoire (Korhogo) et essai de lutte par utilisation d'extraits aqueux de plantes. Journal of Animal \&Plant Sciences, 22 (3): 3455-3468.

Djuideu TCL, Bisseleua DHB, Kekeunou S, Meupia MJ, Difouo FG. and Ambele CF: 2019. Plant community composition and functional characteristics define invasion and infestation of termites in cocoa agroforestry systems. Agroforestry Systems.

Dufumier M: 2016. L'adaptation de la cacaoculture ivoirienne au dérèglement climatique : L'agroécologie pourrait-elle être une solution? Plate-Forme pour le Commerce Equitable.16 p.

Gbenyedji JNBK, Kasseney BD, Nyamador WS, Sanbena BB, Kokutsè AD, Kokou K. and Glitho IA : 2016. Evaluation des attaques des termites (Isoptera, Brullé, 1832) sur quatre essences forestières d'importance économique au Togo (Afrique de l'ouest). European Scientific Journal 12: 333-352.

Hamad M: 1950. The phylogeny of termite genera based on imago-worker mandibles. Bulletin of the American Museum of Natural History (Entomology), 95(2):36-86.

Han SH. And N’Diaye A : 1996. Dégâts causés par les termites (Isoptera) sur les arbres fruitiers dans la région de Dakar (Sénégal). Actes Coll. Insectes sociaux, 10: 111-117.

Holt IA : 1996. Termites and tropical landscapes, Implications for sustainable production. 2- 10. In "Solo Suelo. XIII congresso latini americano de Ciencia do Solo », 4 a 8 agosto. Aguas de Lindora SPBrasil, edition CD ESALQ. 
ICCO : 2019. Rapport, résumé des prévisions et estimations révisées, Août 2019.

Mampouya D: 1997. Les populations de termites d'une culture de canne à sucre irriguée dans un écosystème sahélien, Le fipronil dans une lutte ciblée contre les termites. Thèse d'Université, Université Paris XII- Val de Marne. 151p.

Mora P, Rouland C, Dibangou V. and Renoux $\mathrm{J}:$ 1990. Damage caused by the recent infestation of the sugar cane fields by the fungus-growing termites Pseudacanthotermes spiniger. In Social Insects and the Environment, Veeresh GK, Mallik B, Viraktamath CA (eds). Oxford I.B.H.: New Delhi, India; 604605.

Pretorius MW, Van Ark H. and Mohr JD: 1991. Preliminary mound-fumigation trials for the control of Trinervitermes trinervoides colonies (Isoptera: Termitidae). Phytophylac., 23: 89-90.

Sands WA: 1965. A revision of the termite subfamily Nasutitermitinae (Isoptera, Termitidae) from the Ethiopian region. Bulletin of the British Museum (Natural History), (Entomology), Supplement 4: 1-172.

Sands WA: 1972. The soldierless termites of Africa (Isoptera: Termitidae). Bulletin of the British Museum (Natural History), (Entomology), Supplement. 18: 244 p. + Annexes.

Sands WA: 1998. The Identification of Worker Castes of Termite Genera from Soils of Africa and the Middle East. CAB International \& Natural Resources International, Wallingford, UK, 500.

Su NY: 2002. Current and future trends of termite management. Sociobiology, 40: 12.

Tra Bi CS : 2013. Diversité spécifique et dégâts des termites dans les cacaoyères (Theobroma cacao L., 1759) de la région d'Oumé en Côte D'ivoire. Thèse de Doctorat, Université de Université Félix Houphouët-Boigny, Côte d'Ivoire, 243 $\mathrm{p}+$ annexes.
Vos JGM, Ritchie BJ et Flood J : 2003. A la découverte du cacao. CABI Bioscience, $16 \mathrm{p}$.

Wood TG. and Pearce MJ: 1991. Termites in Africa: the environmental impact of control measures and damage to crops, trees, rangeland and rural buildings. Sociobiology., 19: 221-234.

Wood TG: 1976. The role of termites (Isoptera) in decomposition processes. In: the role of terrestrial and aquatic organisms in decomposition processes. Eds J.M. Anderson \& Macfadyen. Blackwell, Oxford. England. p.145-168. 